\title{
The Effectiveness of Argument-Driven Inquiry in Promoting Students' Argumentation Skills About Colloids
}

\author{
Dessy Rizki Amelia ${ }^{1}$, Asrial $^{2}$, Muhammad Haris Effendi-Hasibuan ${ }^{3 *}$ \\ ${ }^{123}$ Universitas Jambi \\ *Corresponding author.Email:hariseffendi@unja.ac.id
}

\begin{abstract}
This study aimed to investigate the effect of argument-driven inquiry (ADI) in promoting students' argumentation skills about colloidal concepts in comparison to inquiry-based learning (IbL) strategy. Factors that affected the students' skills between the strategies were also identified. Three classes of $11^{\text {th }}$ grade students (ADI-1, ADI-2, IbL) were involved. Data were collected using field-notes and argumentation tests and then analyzed using the interpretive method and the one-way ANOVA test. The results of the ANOVA test showed significant difference of skills amongst the classes (Fvalue $=27.671$, sig<.05). Tukey HSD test however showed that the mean scores of ADI-1 and ADI-2 were indifferent (mean $=88.89 \& 88.48, \mathrm{SD}=4.73 \& 4.40, \mathrm{sig}>.05$ ) but both were significantly different from the $\mathrm{IbL}$ (mean=80.98, $\mathrm{SD}=4.90$, sig<.05). Therefore, ADI was more effective than the IbL strategy in promoting the students' argumentation skills about the colloidal concepts. Different experiences the students had in the three classes were the factor that produced the skill differences between the students.
\end{abstract}

Keywords: Argument-driven inquiry, inquiry-based learning, argumentation skills, colloidal-concepts.

\section{INTRODUCTION}

Argumentation is the process of making statements supported by evidence [1], and this includes skills in making claim, finding evidence/data, composing logical explanation, posing backings, predicting qualifier, and rebuttal [2][3]. Engaging students in those activities is crucial to build their epistemological understanding of science and to develop scientific knowledge [4]. In turn, those activities could develop the quality of Indonesia students' mastery in science [5][6].

Despite the importance of the skills, but these were rarely adopted in science classrooms [7][8][9][10]. Science classrooms were dominated with 'chalk and talk' activities, notes-making, memorization, and simple question and answer activities [11][12][13]. Such activities provide students little chances to exercise their deep-thinking skills [14] that might bring low ability to think critically as well as to make scientific argumentations [10] that in turn will reduce their understanding about science concepts [15]. Therefore, learning strategies that encourage students to nurture their ability to make argumentation need to be involved in science classroom activities [16].

Cooperative learning strategies are effective to promote students' argumentation skills in science [17]. Cooperative learning engages learners to learn together in small groups (4-6 students) to improve their learning by supporting each other [18]. These included jigsaw, two-stay-two-stray (TSTS), discovery learning (DL), and inquiry-based learning (IbL). In our previous study, we had used jigsaw, TSTS, and DL strategies to promote secondary school students' ability in making argumentation in chemistry. We found that these strategies were effective in engaging the students making argumentations about the concept-to-learn [19]. In addition, IbL had also been effective in improving students' knowledge in science, and their reasoning and argumentation skills about the learnedconcept [10].

Some weaknesses, however, were observed. In our previous study, even though the use of jigsaw, TSTS, and DL was able to help students gain the ability to 
make argumentations, but those strategies were not very effective in facilitating the students to produce high quality of argumentations. This was because those strategies were not specifically designed to engage students to make argumentations but were more to help them to understand the concepts of science. Those strategies did not provide the students with prescribed activities and opportunities to make the argumentations. In shorts, the steps of those strategies did not explicitly direct the students about when and how to make the argumentations. As a result, some students were observed confused to construct the argumentations [19]. This finding indicates that a learning strategy which is not tailored with specific steps of making arguments -such as those three - will engage students minimally in making scientific argumentation. Taking this issue into account, we believe that not only do the jigsaw, TSTS, and DL provide minimal opportunities when are used to promote students' argumentation skills but also will the other learning strategies such as IbL.

One strategy specifically-designed with clear steps to do argumentation is argument-driven inquiry (ADI) [20]. ADI provides students with richer and more authentic science experiences. ADI provides students with exposure to community practices that are similar to the scientific community [21]. The students share ideas, collect data, discuss and think about what they know and what they have learned. ADI allows students to design their own research questions and make their own conclusions [22][23].

Given the specification of ADI, it was more effective in improving the quality of Turkey students' argumentation compared to traditional practical methods [24]. ADI promoted high school students with better understanding of the nature of scientific inquiry and arguments [22]. Similarly, argumentation-based guided inquiry was also effective in developing formal reasoning skills of students [25] and conceptual knowledge of misconception-invested pre-service science teachers [26]. ADI had also brought better argumentation skills and content knowledge of teachers who were taking professional development programs [5] that in turn would also affect students' abilities in making argumentations. Moreover, the elementary school students' engagement in learning science had been promoted after being exposed to ADI [27]. Those results confirm that ADI learning is effective to develop students' argumentation skills in science. Thus, teachers were suggested adopting this learning strategy in teaching science.

Despite the effectiveness of ADI, such effectiveness needs to be learned by comparing to other learning strategies such as inquiry-based learning ( $\mathrm{IbL})$. IbL is a science teaching strategy to improve students' skills in making investigation and to enhance their critical thinking skills as well as their science skills [28]. In IbL, students are encouraged to raise questions or hypothesis, collect data to answer the questions, perform cooperative works, share ideas, and carry out discussions with peers [29]. IbL is beneficial in developing students' learning outcomes with larger scopes. These included the development of student's logical thinking ability, concepts mastery, student's ability to identify problems, ability to formulate hypothesis and questions, and student's scientific process skills [30-37].

The comparison between ADI and IbL in promoting student's ability to make scientific argumentation is important for some reasons. First, both strategies have similarities in their learning structures since the construction of ADI by Sampson et al in 2009 might have been inspired by the structure of IbL. Second, even though the structures of both strategies are similar, ADI has more steps ( 9 steps) than IbL (6 steps). This issue may influence teachers' adoptions of ADI in science classrooms due to time constraint. Third, ADI is relatively new and presumably less well-known by science teachers compared to IbL which has been the most used teaching strategy for decades and that is more well-known for teachers [38]. This may also influence teachers' adoption of ADI in their science classes. Fourth, the need for having worthwhile information about an effective learning strategy which can be used to develop students' ability in making scientific argumentations. This information may facilitate teachers who are lack of information about how to prepare their lessons in an argumentative style [39]. In this study, we had used ADI and IbL in chemistry learning and the effectiveness of both in helping students to produce argumentations in the topic of colloidal concepts had been investigated.

Therefore, this study aimed to look at the effectiveness of ADI strategy compared to IbL strategy in promoting secondary school students' argumentation abilities in the concept of colloids. This study aimed to investigate factors that affect the effectiveness of ADI and IbL in developing such abilities in the colloidal concepts. The results of this study will provide convincing evidence about the effectiveness of strategies in helping students to promote their argumentation skills in science. Finally, the results are also contributive to the body of knowledge about how to effectively develop students' abilities in making scientific argumentations. Two questions guided this study as below:

1. How is the effectiveness of ADI and $\mathrm{IbL}$ in promoting students" argumentation skills about colloids?

2. What factors that influenced the difference of effect between the ADI and IbL? 


\section{RESEARCH METHODS}

This study was conducted in the late of 2019 in a Senior High School in Jambi city, Indonesia. A posttest only quasi experimental design was applied in this study since we were unable to control all variables related to the study such as intellectual level, gender, age, etc. This study also omitted pre-tests since the argumentation test was a high-stake test, and the students were novice about this. Thus, the post-test was adequate as the only way to look at the difference in the students' argumentation abilities [40].

Three classes of 11th grade (each 35 students aged 16-17 years) were selected randomly from pre-existing six classes to be the participants of this study and further assigned to be the ADI-1, ADI-2, and IbL class. The use of a duplicate group (ADI-2) aimed to see the internal validity between the ADI-1 and ADI-2 in which both were supposed to give the similar effect on the students' skills in making argumentation and both should show similar standpoint from the IbL. The involvement and exposure of the students was approved and proven by a consent form issued by the school authorities. Moreover, a teacher, Chindy (pseudonym), a female in her 30s was also involved in this study to implement the strategies. She held a master degree in chemistry education with more than 15 years of teaching experience. She joined a workshop about $\mathrm{ADI}$ and inquiry learning prior to the conduct of the study to ensure that she was knowledgeable and skillful in using both strategies.

The learning process of ADI consisted of nine steps [22] and the IbL consisted of 5-6 steps [41]. The learning steps of ADI and IbL can be seen in Table 4. The teacher and the students in each class implemented the strategy for about 270 minutes in three meetings. The students ( 7 groups consisted of 5 students each) in each class needed to learn about the various colloidal systems (meeting 1), the properties of colloidal substances (meeting 2), and the use of colloidal substances in daily life (meeting 3 ).

Data were collected using field-notes on purpose to look for the factors that contribute to the difference of the students' argumentation skills [40]. Meanwhile, an argumentation test was utilized to collect data about the students' ability in making argumentations and was administered after the study. The items of the test asked the students to make a claim/answer, to provide evidence/data, and to post warrants/explanations. The fitness of the test items was validated using a content validity method which involved an expert judgement. The questions are listed in Table 1.

Table 1. The Argumentation Test Questions

\begin{tabular}{|c|l|}
\hline Item No & \multicolumn{1}{c|}{ Questions } \\
\hline 1 & $\begin{array}{l}\text { You are given 3 solutions. Based on the turbidity and light scattering ability, determine which solution } \\
\text { is colloid! Support your answer with data and reasons! }\end{array}$ \\
\hline 2 & $\begin{array}{l}\text { Which one between aluminum chloride and hydrochloric acid is colloid and used in deodorant? Support } \\
\text { your answer with data and reasons! }\end{array}$ \\
\hline 3 & $\begin{array}{l}\text { Based on your experience in making ice cream, determine whether the ice cream can be grouped into } \\
\text { foam or solid! Support your answer with data and reasons! }\end{array}$ \\
\hline
\end{tabular}

The field-notes data were analyzed using the basic qualitative analysis technique involving an interpretive method towards the learning activities [42]. The validity of the data analysis process was achieved by involving the member-checking process and the peerdiscussions amongst the researchers. Meanwhile, the data from the test were analyzed using a rubric developed by previous authors [43]. The validity of the assessment process was conducted using the interrating system involving two researchers. Then, a oneway ANOVA (SPSS-23) test was applied to analyze the data including the descriptive statistics and the Tukey HSD test. The use of this test was granted as of all the data collected from the three classes were normally distributed (Kolmogorov-Smirnov) indicated by the $\mathrm{p}$ value $\geq .05$ (p-value ADI-1=.200, p-value ADI-2=.05 $\& \mathrm{p}$-value $\mathrm{IbL}=.069)$ and the combined data were homogeneous (Levene test) indicated by $\mathrm{F}=.491$ with $\mathrm{p}$-value $=.614>.05$.

\section{RESULTS AND DISCUSSION}

Based on the results of analysis (Table 2), it was found that there was a significant difference of the students' argumentation skills amongst the ADI-1, ADI-2, and the IbL (F-value $=27.671 ; \mathrm{p}$-value $(\mathrm{sig})$ $=.00<.05)$. The students in the class of ADI-1 and ADI-2 had better argumentation abilities (mean score) than those in the IbL class $(88.89,88.48$, and 80.98 respectively). This finding was supported by the mean scale amongst the classes $(4.42,4.42$, and 4.04) and the scale of argumentation in which the students of ADI-1 and ADI-2 were able to produce the scale 5 argumentation $(58.8 \%$ and $64.1 \%)$ while the IbL 
students were able to produce the scale 3 and 4 argumentation $(22.9 \%$ and $41.2 \%)$.

Table 2. Students' Argumentation Skill

\begin{tabular}{|c|c|c|c|c|c|c|c|}
\hline \multirow{2}{*}{$\begin{array}{l}\text { Learning } \\
\text { Strategies }\end{array}$} & \multirow[t]{2}{*}{$\overline{\text { ANOVA }}$} & \multirow{2}{*}{$\begin{array}{l}\text { Mean } \\
\text { Score }\end{array}$} & \multirow{2}{*}{$\begin{array}{l}\text { Standard } \\
\text { Deviation }\end{array}$} & \multirow{2}{*}{$\begin{array}{l}\text { Mean of } \\
\text { Scale }\end{array}$} & \multicolumn{3}{|c|}{ Scale of Argumentation } \\
\hline & & & & & $\overline{3}$ & 4 & 5 \\
\hline ADI 1 & $\mathrm{~F}=27.671$ & 88.89 & 4.73 & 4.42 & 15.9 & 25.3 & 58.8 \\
\hline ADI 2 & $\mathrm{p}$-value $($ Sig $)=$ & 88.48 & 4.40 & 4.42 & 21.6 & 14.3 & 64.1 \\
\hline IbL & .00 & 80.98 & 4.90 & 4.04 & 22.9 & 41.2 & 27.3 \\
\hline
\end{tabular}

To see whether or not a difference also existed between one class and another class, the Tukey HSD test was applied. Based on the test (Table 3), it is seen that there was not significant difference between ADI1 and ADI-2 (p-value sig $=.997>.05)$ but significant difference presented between both (ADI-1 \& ADI-2) and the $\mathrm{IbL}$ ( $\mathrm{p}$-value sig $=.000<.05)$. This finding affirms the above result that the ADI strategy was more effective than the IbL in improving students' argumentation abilities in the sampled classes.

Table 3. The Result of Multiple Comparison

\begin{tabular}{|c|c|c|c|c|c|c|}
\hline Cat (I) model & model & $\begin{array}{c}\text { Mean Difference } \\
(\text { I-J) }\end{array}$ & Std. Error & Sig. & \multicolumn{2}{|c|}{$95 \%$ Confidence Interval } \\
\cline { 5 - 7 } & ADI-2 & .08163265 & 1.14236467 & .997 & -2.6370167 & 2.8002820 \\
\hline ADI-1 & IbL & $-7.58928571^{* *}$ & 1.16845292 & .000 & -10.3700210 & -4.8085504 \\
\hline ADI-1 & IbL & $7.50765306^{*}$ & 1.16033151 & .000 & 4.7462454 & 10.2690607 \\
\hline
\end{tabular}

The current finding presenting the higher effectiveness of the ADI learning strategy compared to the IbL strategy in developing the students' abilities in making argumentations was reasonable. Based on the results of field-notes observations conducted in the respected classes for three meetings (270 minutes in total), it was seen that the students in the ADI and IbL classes had different learning activities (Table 4). At the early steps, the teacher (she) treated the students in the three classes in a similar way. She delivered the contents and encouraged the students to identify problems. She also facilitated them to make hypotheses and to collect data. However, her treatments to the students were different afterwards. She facilitated the ADI students to make tentative arguments that included the making of claims, the finding of evidence/data, and the composing of reasons/explanations. She further encouraged the students to discuss their argumentations, make reports, perform double-blind review, and even she facilitated the students to revise their reviewed reports. On the other hand, in the IbL class, she only ordered the students to examine the hypothesis to make explanations. At the end of the lesson, she treated the students in a similar way again. She encouraged the students to perform classroom discussions to make conclusions. The difference of the students' learning experience particularly in the argumentation making activities seemingly caused the difference in effectiveness between the ADI and the IbL.
The superiority of ADI in enhancing the students' ability to make argumentation compared to IbL was also caused by the difference in the structure of both strategies. The structure of ADI was specifically designed to engage the students in argument-making activities. The structure of ADI consisted of steps which directed the students to make such argumentations. From the data in Table 4, it is seen that the ADI strategy consisted of 5 steps out of the 9 steps that engaged the students in the tasks of argument making. These were the steps of tentative argumentation making (step no 4), the step of argumentative discussion (step 5), the step of report writing (step 6), the step of peer reviewing (step 7), and the step of report revising (step 8). Demircioglu and Ucar affirmed that these steps improve the students' critical thinking skills that in turn will help the students to correct their shortcomings in argument making [24]. This is in accordance with what said by Sampson and Gleim that the ADI learning strategy is designed to achieve the objectives of scientific inquiry in an effort to develop an argument that supports the explanation of a research question [39]. 
Table 4. The Results of Observations

\begin{tabular}{|c|c|c|c|}
\hline ADI (270 minutes) & Inquiry (270 minutes) & Learning process & Interpretations \\
\hline 1. Content delivery (30 mins) & $\begin{array}{l}\text { 1. Content delivery (40 } \\
\text { mins) }\end{array}$ & \multirow{4}{*}{$\begin{array}{l}\text { The students in both classes were } \\
\text { delivered the contents, } \\
\text { encouraged to identify problems, } \\
\text { hypothesis, and were encouraged } \\
\text { to collect data. }\end{array}$} & \multirow{4}{*}{$\begin{array}{l}\text { Similar activities } \\
\text { and experiences }\end{array}$} \\
\hline 2. Problems identification (15 mins) & $\begin{array}{l}\text { 2. Problems/questions } \\
\text { formulation (40 mins) }\end{array}$ & & \\
\hline NA & $\begin{array}{l}\text { 3. Hypothesis formulation } \\
\text { (40 mins) }\end{array}$ & & \\
\hline 3. Data collection (30 mins) & 4. Data collection (60 mins) & & \\
\hline $\begin{array}{l}\text { 4. Tentative argument making: } \\
\text { Claim making ( } 15 \text { mins), data } \\
\text { finding ( } 15 \text { mins), and reasons } \\
\text { posing ( } 30 \text { mins) }\end{array}$ & $\begin{array}{l}\text { 5. Hypothesis testing by } \\
\text { making explanation ( } 60 \\
\text { mins) }\end{array}$ & $\begin{array}{l}\text { ADI students had activities to } \\
\text { compose arguments while the } \\
\text { Inquiry students did not }\end{array}$ & $\begin{array}{c}\text { Different } \\
\text { activities and } \\
\text { experiences }\end{array}$ \\
\hline $\begin{array}{l}\text { 5. Argumentative discussion ( } 30 \\
\text { mins) }\end{array}$ & NA & \multirow{4}{*}{$\begin{array}{l}\text { ADI students had } 4 \\
\text { argumentation-oriented activities } \\
\text { but the inquiry students did not }\end{array}$} & \multirow{4}{*}{$\begin{array}{c}\text { Different } \\
\text { activities and } \\
\text { experiences }\end{array}$} \\
\hline 6. $\quad$ Reports writing (30 mins) & NA & & \\
\hline $\begin{array}{l}\text { 7. Double-blind peer review (30 } \\
\text { mins) }\end{array}$ & NA & & \\
\hline 8. Revision of reports (15 mins) & NA & & \\
\hline $\begin{array}{l}\text { 9. Classroom discussion to make } \\
\text { conclusion (30 min) }\end{array}$ & $\begin{array}{l}\text { 6. Classroom discussion to } \\
\text { make conclusion ( } 30 \\
\text { mins) }\end{array}$ & $\begin{array}{l}\text { The students in both classes made } \\
\text { conclusions. }\end{array}$ & $\begin{array}{l}\text { Similar activities } \\
\text { and experiences }\end{array}$ \\
\hline
\end{tabular}

In contrast, the IbL structure was not specifically designed to engage the students in argument-making activities. The steps of IbL did not strongly direct the students to make such argumentations. Rather, IbL was designed on purpose more to improve students' skills in making investigation and to enhance their critical thinking skills as well as their science skills [29]. In IbL, teachers are recommended engaging students to work independently, to carry out investigations, to collect their own data, and to reach their own conclusions [44]. This means that students in IbL are not prescribed to make scientific argumentation that links their answer or claim with their data and explanation. Truthfully, in IbL, teachers may invite students to make argumentation, but, unfortunately, it is not prescribed for them to do so. Hence, unarguably, sometimes teachers forget to instruct students to make such argumentations.

Therefore, the effectiveness of the ADI came from the intense steps of ADI related to the argument making tasks. This way, the teacher was clearly driven to engage the students to make argumentations. Meanwhile, the inquiry strategy did not consist of any step of engaging the students to do so. In shorts, making argumentation is prescribed in the ADI learning while in $\mathrm{IbL}$ is not. ADI provided students with different learning experience compared to the students in the $\mathrm{IbL}$ class. Moreover, ADI facilitates students with many opportunities to engage in argumentative discussions and activities [22][3]. This is in line with previous authors who had reckoned that ADI was effective to facilitate students with many opportunities to be engaged in argumentative discussions and activities [39][22][23]. Thus, Gümrah \& Kabapınar argued that students who embrace argumentation-related learning instructions significantly outperform those who learn using common constructivism-based learning instructions such as $\mathrm{IbL}$ in terms of conceptual understanding in chemistry [6]. These findings asserted that the argument-driven inquiry (ADI) learning strategy involves students in more intensive argumentation activities than the inquiry strategy. This is the critical point that distinguishes the ADI from IbL.

Finally, the results of this study were supported by what had been reckoned by previous authors saying that cooperative learning strategies were beneficial in promoting students' skills in making arguments [45, 17] particularly strategies that drove students to make argumentations. These findings also parallel with the results of our other study that investigated the effectiveness of an argument-based learning strategy (AbL) which we designed purposefully to intensively engages students in the steps of making argumentations. We found that the AbL had been able to increase the ability of the University of Jambi students to make arguments about the socio-chemistry issues. We also found that the AbL was more effective in helping the university students to enhance their abilities in making argumentation about the dangerous of heavy metals on human's health compared to the conventionally available cooperative learning strategies such as jigsaw and two-stay-two-stray (TSTS) [43]. This suggested that the more a learning strategy provides students with opportunities to make argumentations the more effective the strategy is in helping students promote their ability to make scientific argumentations. 


\section{CONCLUSIONS AND IMPLICATIONS}

The argument-driven inquiry had been successful in promoting the students' argumentation skills in the concept of colloids and even more effective than the inquiry-based learning. Students who learned the concepts using ADI had better argumentation abilities compared to those who learned using IbL strategy. The high intensity of the ADI in engaging the students in the activities to make argumentations was the factor that made the ADI to be more effective than the IbL strategy. Further researches are needed to investigate the effectiveness of ADI in developing students' argumentation skills in the topic of Physics, Biology and Math to provide richer evidence about ADI implementation facilitating diverse students' learning experience in those subjects. To sum up, even though ADI has more steps than IbL, the results of this study may provide valuable information for science teachers about the effectiveness of ADI in enhancing students' abilities to make scientific argumentation. Thus, this information would expectedly increase teacher's attention and adoption of ADI in science teaching.

\section{AUTHORS' CONTRIBUTIONS}

Author 1: contribute to primary and secondary data and analysis theory

Author 2 and 3: contribute to data processing and manuscripts

\section{REFERENCES}

[1] K. -L. Cho, \& D. H. Jonassen. (2002). The effects of argumentation scaffolds on argumentation and problem solving. Educational Technology Research and Development, 50(3), 5-22. https://doi.org/10.1007/BF02505022

[2] S. E. Toulmin. (2003). The Uses of Argument. In The Uses of Argument: Updated Edition. https://doi.org/10.1017/CBO9780511840005

[3] V. Dawson, \& K. Carson. (2016). Using climate change scenarios to assess high school students' argumentation skills. Research in Science and Technological Education, 35(1), 1-16. https://doi.org/10.1080/02635143.2016.1174932

[4] R. Driver, P. Newton, \& J. Osborne. (2000). Establishing the norms of scientific argumentation in classrooms. Science Education, 84(3), 287-312. https://doi.org/10.1002/(sici)1098237x(200005)84:3<287::aid-sce1>3.3.co;2-1

[5] B. Cavlazoglu, \& C. Stuessy. (2018). Examining Science Teachers' Argumentation in a Teacher Workshop on Earthquake Engineering. Journal of Science Education and Technology, 27(4), 348-361. https://doi.org/10.1007/s10956-0189728-2

[6] A. Gümrah \& F. Kabapınar. (2010). Designing and evaluating a specific teaching intervention on chemical changes based on the notion of argumentation in science. Procedia - Social and Behavioral Sciences, 2(2), 1214-1218. https://doi.org/10.1016/j.sbspro.2010.03.175

[7] D. H. Jonassen \& B. Kim. (2010). Arguing to learn and learning to argue: Design justifications and guidelines. Educational Technology Research and Development, 58(4), 439-457. https://doi.org/10.1007/s11423-009-9143-8

[8] J. Osborne. (2010). Arguing to learn in science: The role of collaborative, critical discourse. Science, 328(5977), 463-466. https://doi.org/10.1126/science.1183944

[9] Viyanti. (2015). The profile of argumentation skill using "Toulmin argumentation pattern" analysis in the archimedes principal on the students of SMA kota Bandar lampung. Jurnal Pendidikan IPA Indonesia, 4(1), 86-89. https://doi.org/10.15294/jpii.v4i1.3506

[10] C. D. Wilson, J. A. Taylor, S. M. Kowalski \& J. Carlson (2010). The relative effects and equity of inquiry-based and commonplace science teaching on students' knowledge, reasoning, and argumentation. Journal of Research in Science Teaching, 47(3), 276-301. https://doi.org/10.1002/tea.20329

[11] P. Almeida \& F. N. Souza de. (2010). Questioning profiles in secondary science classrooms. Int. J. Learning and Change, 4(3), 237-251. https://doi.org/10.1504/IJLC.2010.035833

[12] W. B. Khan, \& H. M. Inamullah. (2011). A study of lower-order and higher-order questions at secondary level. Asian Social Science, 7(9), 149152. https://doi.org/10.5539/ass.v7n9p149

[13] T. Y. Peen, \& M. Y. Arshad. (2017). Collaborative and Self-Directed Learning Processes: A Case Study in Malaysian Chemistry $\mathrm{PbL}$ Lesson. Indonesian Journal of Educational Review, 4(1), 1-13. https://doi.org/https://doi.org/10.21009/IJER.04. 01.01

[14] P. Newton, R. Driver, \& J. Osborne. (1999). The place of argumentation in the pedagogy of school science. International Journal of Science Education, 21(5), 553-576. https://doi.org/10.1080/095006999290570

[15] I. L. L. Ping \& K. Osman. (2019). Laboratorymodified argument driven inquiry (LAB-MADI) module: Content validity process. Jurnal Pendidikan IPA Indonesia, 8(1), 129-140. https://doi.org/10.15294/jpii.v8i1.16867

[16] M. B. Sherry. (2014). Indirect Challenges and Provocative Paraphrases: Using Cultural Conflict-Talk Practices to Promote Students' Dialogic Participation in Whole-Class Discussions. Research in the Teaching of English, 49(2), 141-167. Retrieved from http://www.jstor.org/stable/24398672 
[17] C. Matuk. (2015). Argumentation Environment. In R. Gunstone (Ed.), Encyclopedia of science education. https://doi.org/10.1007/978-94-0072150-0

[18] W. Jolliffe. (2007). Cooperative Learning in the Classroom: Putting it into Practice. Retrieved from http://sk.sagepub.com/books/cooperativelearning-in-the-classroom

[19] M. H. Effendi-Hsb, Harizon, Ngatijo, Fuldiaratman, \& Sulistyo, U. (2019). Promoting indonesian secondary school students' argumentation skills in the concept of chemistry reaction-rate: A comparative effect of three cooperative learning strategies. Journal of Physics: Conference Series, 1317(1). https://doi.org/10.1088/17426596/1317/1/012143

[20] V. Sampson, J. Grooms, \& J. P. Walker. (2009). Argument-driven inquiry: A way to promote learning during laboratory activities. Science Teacher, 76(8), 42-47. https://doi.org/10.12691/education-3-9-20

[21] J. P. Walker, V. Sampson, \& C. O. Zimmerman. (2011). Argument-driven inquiry: An introduction to a new instructional model for use in undergraduate chemistry labs. Journal of Chemical Education, 88(8), 1048-1056. https://doi.org/10.1021/ed100622h

[22] V. Sampson, J. Grooms, \& J. P. Walker. (2011). Argument-Driven Inquiry as a way to help students learn how to participate in scientific argumentation and craft written arguments: An exploratory study. Science Education, 95(2), 217-257. https://doi.org/10.1002/sce.20421

[23] V. Sampson, \& J. P. Walker. (2012). ArgumentDriven Inquiry as a Way to Help Undergraduate Students Write to Learn by Learning to Write in Chemistry. International Journal of Science Education, 34(10), 1443-1485. https://doi.org/10.1080/09500693.2012.667581

[24] T. Demircioglu \&S. Ucar. (2015). Investigating the effect of argument-driven inquiry in laboratory instruction. Kuram ve Uygulamada Egitim Bilimleri, 15(1), 267-283. https://doi.org/10.12738/estp.2015.1.2324

[25] O. Acar \& B. R. Patton. (2012). Argumentation and Formal Reasoning Skillsin an Argumentation-Based Guided Inquiry Course. Procedia - Social and Behavioral Sciences, 46, 4756-4760.

https://doi.org/10.1016/j.sbspro.2012.06.331

[26] Ö. Acar. (2014). Scientific reasoning, conceptual knowledge, \& achievement differences between prospective science teachers having a consistent misconception and those having a scientific conception in an argumentation-based guided inquiry course. Learning and Individual Differences, $\quad 30, \quad 148-154$. https://doi.org/10.1016/j.lindif.2013.12.002

[27] H. T. Chen, H. H. Wang, Y. Y, Lu, H. S. Lin, \&
Z. R. Hong. (2016). Using a modified argumentdriven inquiry to promote elementary school students' engagement in learning science and argumentation. International Journal of Science Education, $\quad 38(2), \quad 170-191$. https://doi.org/10.1080/09500693.2015.1134849

[28] W. E. Herman, \& M. R. Pinard. (2015). Critically Examining Inquiry-Based Learning: John Dewey in Theory, History, and Practice. In Innovations in Higher Education Teaching and Learning (Vol. 3, pp. 43-62) https://doi.org/10.1108/S2055364120150000003016

[29] M. H. Effendi-Hasibuan, Harizon, Ngatijo, \& A. Mukminin. (2019). The inquiry-based teaching instruction (IbTI) in Indonesian secondary education: What makes science teachers successful enact the curriculum? Journal of Turkish Science Education, 16(1), 18-33. https://doi.org/10.12973/tused.10263a

[30] R. Geier, P. C. Blumenfeld, R. W. Marx, J. S. Krajcik, B. Fishman, E. Soloway \& J. ClayChambers. (2008). Standardized test outcomes for students engaged in inquiry-based science curricula in the context of urban reform. Journal of Research in Science Teaching, 45(8), 922939. https://doi.org/10.1002/tea.20248

[31] C. E. Hmelo-Silver, R. G. Duncan, \& C. A. Chinn. (2007). Scaffolding and achievement in problem-based and inquiry learning: A response to Kirschner, Sweller, and Clark (2006). Educational Psychologist, 42(2), 99-107. https://doi.org/10.1080/00461520701263368

[32] A. Hofstein, O. Navon, M. Kipnis, \& R. MamlokNaaman. (2005). Developing students' ability to ask more and better questions resulting from inquiry-type chemistry laboratories. Journal of Research in Science Teaching, 42(7), 791-806. https://doi.org/10.1002/tea.20072

[33] D. Lustick. (2009). The Failure of Inquiry: Preparing Science Teachers with an Authentic Investigation. Journal of Science Teacher Education, 20(6), 583-604. https://doi.org/10.1007/s10972-009-9149-4

[34 D. D. Minner, A. J. Levy, \& J. Century. (2010). Inquiry-based science instruction-what is it and does it matter? Results from a research synthesis years 1984 to 2002. Journal of Research in Science Teaching, 47(4), 474-496. https://doi.org/10.1002/tea.20347

[35] D. H. Palmer. (2009). Student interest generated during an inquiry skills lesson. Journal of Research in Science Teaching, 46(2), 147-165. Retrieved

from http://dx.doi.org/10.1002/tea.20263

[36] I. Sadeh, \& M. Zion. (2009). The development of dynamic inquiry performances within an open inquiry setting: A comparison to guided inquiry setting. Journal of Research in Science Teaching, 46(10), 1137-1160. Retrieved from 
http://dx.doi.org/10.1002/tea.20310

[37] M. Zion, S. Cohen, \& R. Amir. (2007). The spectrum of dynamic inquiry teaching practices. Research in Science Education, 37(4), 423-447. https://doi.org/10.1007/s11165-006-9034-5

[38] M. H. Effendi-Hasibuan, Ngatijo, \& U. Sulistiyo. (2019). Inquiry-based learning in Indonesia: Portraying supports, situational beliefs, and chemistry teachers' adoptions. Journal of Turkish Science Education, 16(4), 538-553. https://doi.org/10.36681/tused.2020.6

[39] V. Sampson, \& L. Gleim. (2009). ArgumentDriven Inquiry To Promote the Understanding of Important Concepts \& Practices in Biology. The American Biology Teacher, 71(8), 465-472. https://doi.org/10.1662/005.071.0805

[40] J. W. Creswel. (2012). Educational Research: Planning, Conducting and Evaluating Quantitative and Qualitative Research (4th ed.). Retrieved from https://www.pdfdrive.com/educational-researchplanning-conducting-and-evaluatingd16448388.html

[41] M. Pedaste, M. Mäeots, L. A. Siiman, T. de Jong, S. A. N. van Riesen, E. T. Kamp, E. Tsourlidaki. (2015). Phases of inquiry-based learning: Definitions and the inquiry cycle. Educational
Research Review, 14, 47-61. https://doi.org/10.1016/j.edurev.2015.02.003

[42] J. W. Creswell. (2009). Research Design: Qualitative, Quantitative, and Mixed Methods Approaches (3rd ed.). Retrieved from http://books.google.com/books?id=bttwENORfh gC\&pgis $=1$

[43] M. H. Effendi-Hasibuan, A. Bakar, \& Harizon. (2020). Skills to argue: Using argument-based learning (AbL) and socio-scientific issues to promote university students' argumentation skills in chemistry. Journal of Physics: Conference Series, 1567(2). https://doi.org/10.1088/17426596/1567/2/022042

[44] W. P. Baker \& K. Leyva. (2003). What Variables Affect Solubility? Science Activities: Classroom Projects and Curriculum Ideas, 40(1), 23-26. https://doi.org/10.1080/00368120309601109

[45] R. Khishfe \& N. Lederman. (2006). Teaching nature of science within a controversial topic: Integrated versus nonintegrated. Journal of Research in Science Teaching, 43(4), 395-418. https://doi.org/10.1002/tea.20137 